\title{
Commercial Union Assurance Companies v. Safeway Stores, Inc.: Liability of Insureds and Primary Insurers to Excess Insurers for Unreasonable Failure to Settle Claims
}

In Commercial Union Assurance Companies v. Safeway Stores, Inc. ' the California Supreme Court resolved a split in the courts of appeal in a relatively uncharted but rapidly developing area of the law: the liability of insureds and primary insurers to excess insurers for unreasonable failure to settle claims. ${ }^{2}$ Many insureds take out two types of insurance: primary insurance, which covers liability up to a certain amount, and excess insurance, which covers liability over that amount. ${ }^{3}$ In most cases, the primary insurer has control over the defense in liability actions brought against the insured. ${ }^{4}$ Where the primary insurer refuses a settlement offer within its policy limits, and ultimate liability exceeds those limits, thus imposing liability on the excess insurer, a possible conflict arises. The excess insurer may feel that the primary's refusal was in bad faith, and that the primary should be liable to the excess insurer for those amounts that it had to pay as a result of that refusal. In some cases, the insured may be the party refusing settlement. The liability of the imsured to the excess insurer in such a situation was the subject of the Commercial Union case.

In Transit Casualty Co. v. Spink Corp., 5 the Court of Appeal for the Third District held that an excess insurer could sue its insured for an unreasonable refusal to settle a claim below the lower limits of the decision).

1. 26 Cal. 3d 912, 610 P.2d 1038, 164 Cal. Rptr. 709 (1980) (by the court) (unanimous

2. One commentator has noted an abnormal number of court opinions dealing with the extent of a primary insurer's duty to an excess insurer in 1977-1978 as compared with previous years. Lanzone, Duties Owed by a Primary Insurer and an Insured with a Self-Insured Retention to an Excess Insurer-An Updale, 28 FED'N OF INS. COUNSEL Q. 267 (1978).

3. For a discussion of the different types of excess insurance, see note 57 infra.

4. See text following note 51 infra.

5. 94 Cal. App. 3d 124, 156 Cal. Rptr. 360 (3d Dist. 1979), disapproved in part, Commercial Union Assur. Cos. v. Safeway Stores, Inc., 26 Cal. 3d 912, 921, 610 P.2d 1038, 1043, 164 Cal. Rptr. 709,714 (1980). 
excess coverage. ${ }^{6}$ The Spink court also held that a primary insurer owes the same duty of care to the excess insurer im settlement negotiations that it owes to the insured. In contrast, the Court of Appeal for the First District held in Commercial Union ${ }^{7}$ that an excess insurer could not sue its insured for a bad faith failure to settle. The Commercial Union court also held that a primary insurer owes no direct duty to an excess insurer. ${ }^{8}$ On appeal, the supreine court affirmed the Commercial Union court on both issues.

Part I of this Note traces the development of the bad faith causes of action against insurers and insureds. Part II presents the facts and the appellate courts' reasoning in Spink and Commercial Union. Part III analyzes this reasoning and the nature of excess insurance and argues that the supreme court reached the correct result.

I

LEGAL BACKGROUND

\section{A. Development of the Cause of Action for Bad Faith Failure to Settle in California}

In Brown v. Guarantee Insurance Co. ${ }^{9}$ and Comunale v. Traders \& General Insurance Co.,$^{10}$ the California courts established that insurers are bound by a duty of good faith and fair dealing toward their insured in conducting settlement negotiations of claims against the insured. This duty is based on the conclusion that the insured has the right to assume that its interests will not be neglected by the insurer, which, under most insurance contracts, has the exclusive right to defend claims agamst the insured and to decide whether or not to settle. "

The Brown court declined to base the insurer's hability on a negligence standard. Instead, the court based the insurer's duty on the contractual notion of an imphed covenant of good faith and fair dealing, requirmg both parties to refrain from doing anything to injure the right of the other to receive the benefits of the bargain. ${ }^{12}$ The Comunale 18 infra.

6. This is the reverse of the traditional bad faith situation. See text accompanying notes 9-

7. 158 Cal. Rptr. 97 (1st Dist. 1979), affd, 26 Cal. 3d 912, 610 P.2d 1038, I64 Cal. Rptr. 709 (1980). The court of appeal opinion was officially depublished by the supreme court; therefore, it cannot be cited before the California courts.

8. Teclnically, the court's statements concerning the primary insurer are dicta, because only the insured and the excess insurer were involved in the appeal of the case. The court's statements slould be considered determinative, however, as it grarted a learing of the case specifically to resolve this issue.

9. 155 Cal. App. 2d 679, 319 P.2d 69 (2d Dist. 1957).

10. 50 Cal. 2d 654, 328 P.2d 198 (1958).

11. Id. at 660,328 P.2d at 201; Brown v. Guarantee Ins. Co., 155 Cal. App. 2d at 684, 319 P.2d at 72.

12. 155 Cal. App. 2d at 687-89, 319 P.2d at 74-75. The appellate court in Brown listed several factors that a court slould consider in determining whetler there was bad faith in a particular 
court retained bad faith as the standard for assessing liability, and also allowed the plaintiff two procedural advantages of a contract action. ${ }^{13}$ But the court also expressly recognized that a wrongful refusal to settle sounds both in contract and tort and the plaintiff could elect between an action in tort and one in contract. ${ }^{14}$

In Crisci $v$. Security Insurance Co. ${ }^{15}$ the supreme court considered a case in which the insurer's failure to settle a claim within policy limits subjected the insured to considerable financial hardship and mental distress. The court held that bad faith is present where a prudent insurer without policy limits would have accepted the offered settlement. ${ }^{16}$ The court also held that the return of a verdict above the policy limits raises a rebuttable inference that settlement within the policy limits was the most prudent way to dispose of the claim. ${ }^{17}$ The court also supported the suggestion in Comunale that the duty to accept reasonable settlements sounds in both contract and tort by allowing recovery for mental suffering resulting from the failure to settle. ${ }^{18}$ Thus, the

case. These included the strength of the injured claimant's case on the issues of damages and liability; attempts by the insurer to induce the insured to contribute to a settlement; failure of the insurer to investigate the circumstances properly in order to ascertain the strength of the case against the insured; rejection by the insurer of the advice of its own attorney or agent; failure to inform the insured of a compromise offer; fault of the insured in inducing the insurer's rejection of a settlement offer by misleading it as to the facts; the amount of financial risk to which each party would be exposed in the case of an adverse judgment; and other factors that might tend to establish or negate bad faith on the part of the insurer. Id. at 689, 319 P.2d at 75. Several of these factors would be equally applicable under a negligence standard. For a suggestion that the bad faith and negligence standards are in practical terms indistinguishable, see $7 \mathrm{C} \mathrm{J}$. APPLEMAN, INSURANCE LAW AND PRACTICE § 4712, at 425 (Berdal ed. 1979).

13. Id. at 659, 661-62, 328 P.2d at 201, 202-03. First, it allowed the insured to assign its cause of action against the insurer to the injured claimant without first receiving the consent of the insurer, because consent is not required to assign a cause of action for breach of contract. Second, the court held that the bad faith cause of action was founded on a written contract. Thus, the four-year statute of limitations governing lawsuits based on contracts is applicable, rather than the shorter limitations period applicable to actions based on unwritten or "implied" obligations or grounded in tort. See CAL. Civ. Proc. Code $\$ 340$ (West Supp. 1981).

14. 50 Cal. $2 \mathrm{~d}$ at 663,328 P.2d at 203.

15. 66 Cal. 2d 425, 426 P.2d 173, 58 Cal. Rptr. 13 (1967).

16. Id. at 429,426 P.2d at 176,58 Cal. Rptr. at 16.

17. Id. at 431, 426 P.2d at 177, 58 Cal. Rptr. at 17. See also Johansen v. California State Auto. Ass'n Inter-lns. Bureau, I5 Cal. 3d 9, 17, 538 P.2d 744, 749, 123 Cal. Rptr. 288, 293 (1975); Northwestern Mut. Ins. Co. v. Farmers Ins. Group, 76 Cal. App. 3d 1031, 1054, 143 Cal. Rptr. 415, 429 (4th Dist. 1978).

18. $66 \mathrm{Cal}$. $2 \mathrm{~d}$ at $432-33,426 \mathrm{P} .2 \mathrm{~d}$ at $178,58 \mathrm{Cal}$. Rptr. at 18. The court's treatment of the bad faith cause of action as a tort for remedy purposes raises the possibility that punitive damages might be assessed against the insurer for a bad faith refusal to settle a claim. While this question has not yet come before the courts, punitive damages have been awarded in California against an insurer guilty of bad faith in its handling of an insured's claim against it. See Neal v. Farmers Ins. Exch., 21 Cal. 3d 910, 582 P.2d 980, 148 Cal. Rptr. 389 (1978), in which the court assessed punitive damages for a refusal to pay uninsured motorist benefits to the insured under an automobile insurance policy; the court treated the insurer's consistent refusal to settle the insured's underlying personal injury claim as evidence of bad faith. 
bad faith cause of action has many of the procedural advantages of contract litigation and is measured by a contract standard of liability, but the remedy resembles that in a tort action.

\section{B. Evolution of "Reverse Bad Faith": Excess Insurers versus Primary Insurers}

An excess insurer's cause of action against a primary imsurer for the primary carrier's bad faith refusal to settle a claim within its policy limits developed as a result of equitabie subrogation to the insured's bad faith claim rather than from an imdependent duty owed by the primary to protect the imterests of the excess insurer. In American Fidelity \& Casualty Co. v. All American Bus Lines, ${ }^{19}$ a federal court applying Oklahoma law allowed an excess carrier's action to proceed under the doctrine of equitable subrogation despite the lack of contractual privity between the two insurers. The court held that the excess imsurer, by paying the excess judgment against the insured, assumed the position of the insured with respect to the primary insurer. Thus, the excess insurer inherited any cause of action for bad faith that the insured itself may have had.

In California, equitable subrogation between insurers first appeared in a federal court case, Peter v. Travelers Insurance Co. ${ }^{20}$ The Peter court set forth three requireinents that must be met for an excess insurer to have a cause of action against a primary insurer. First, the insured must suffer a loss for which the defendant in the subrogation action is responsible. Second, the plaintiff in the subrogation action must compensate the insured for that loss. Finally, justice inust demand that the loss be shifted to the culpable party. ${ }^{21}$ The court einphasized that the interests of an excess carrier that has paid a judgment against the insured are identical to those of an insured that has paid a. judgment in the absence of excess insurance. The excess insurer's cause of action does not expand the primary insurer's duty to accept reasonable settlements. Rather, it prevents a contraction of the primary insurer's duty. ${ }^{22}$ To relieve the primary insurer of the responsibility to accept reasonable settlenents merely because there is an excess carrier to absorb the additional loss, the court stated, would distort the risk that the excess carrier agreed to undertake and would discourage settlements where the settlement offer approaches the primary insurer's pol-

19. 190 F.2d 234 (10th Cir. 1951).

20. 375 F. Supp. 1347 (C.D. Cal. 1974). See also Valentine v. Aetna Ins. Co., 564 F.2d 292 (9th Cir. 1977). For a discussion of these and related caes, see Lanzone, supra note 2, at 268-75.

21. 375 F. Supp. at 1350 (citing Patent Scaffolding Co. v. William Simpson Const. Co., 256 Cal. App. 2d 506, 509, 64 Cal. Rptr. 187, 190 (2d Dist. 1967)).

22. 375 F. Supp. at 1350. 
icy limits. ${ }^{23}$

The first California state court to consider an excess insurer's bad faith claim against a primary insurer came to the same conclusion. In Northwestern Mutual Insurance Co. v. Farmers Insurance Group, ${ }^{24}$ the Fourth District Court of Appeal allowed an excess insurer to rccover an excess judgment from the primary insurer on a showing that the primary carrier's unreasonable refusal to settle within the primary policy limits led to the excess judgment against the insured. The court based its result on equitable subrogation grounds, stating that the lack of privity between the two insurers precluded recovery on a covenantal bad faith tlieory. ${ }^{25}$

In recent years, several jurisdictions have permitted suits between excess and primary insurers based on equitable subrogation. ${ }^{26} \mathrm{~A}$ ininority of courts have held that a primary carrier owes the cxcess carrier the same duty of care that it owes to the insured. ${ }^{27}$

II

\section{The Cases}

In Transit Casualty Co. v. Spink Corp. ${ }^{28}$ the Third District Court

23. Id. at 1350-5I. Northwestern Mut. Ins. Co. v. Farmers Ins. Group, 76 Cal. App. 3d 1031, 1048, 143 Cal. Rptr. 415, 425 (4th Dist. 1978), illustrates the disincentive to settle:

Assum[e] a case in which the primary policy limit is $\$ 20,000$, the excess policy limit is $\$ 50,000$, the reasonable settlement offer is $\$ 18,000$, liability is likely but not certain, and the damages are such that, if recovery is had, it will likely be in an amount well in excess of the primary policy limit. In such a situation, if the primary insurer is not faced with the possibility of liability for failure to effect settlement, it will have at risk only $\$ 2,000$ if it refuses to settle for $\$ 18,000$ and proceeds to trial on the possibility of a favorable judgment. If the reasonable settlement offer were $\$ 20,000$, it would risk nothing at all by going to trial.

24. 76 Cal. App. 3d 1031, 143 Cal. Rptr. 415 (4th Dist. 1978).

25. Id. at 1050,143 Cal. Rptr. at 426.

26. See, e.g., Continental Cas. Co. v. Reserve Ins. Co., 307 Minn. 5, 238 N.W.2d 862 (1976); Allstate Ins. Co. v. Reserve Ins. Co., 116 N.H. 806, 373 A.2d 339 (1977); Estate of Penn v. Amalgamated Gen. Agencies, 148 N.J. Super. 419, 372 A.2d 1124 (1977); Home Ins. Co. v. Nationwidc Mut. Ins. Co., 277 N.C. 216, 176 S.E.2d 751 (1970) (equitable subrogation allowed for refusal to defend suit against insured); Centennial Ins. Co. v. Liberty Mut. Ins. Co., 62 Ohio St. 2d 221, 404 N.E.2d 759 (1980). Contra, Universal Underwriters Ins. Co. v. Dairyland Mut. Ins. Co., 102 Ariz. 518,433 P.2d 966 (1967) (rejecting equitable subrogation theory as well as direct liability toward excess carrier).

27. St. Paul-Mercury Indem. Co. v. Martin, 190 F.2d 455 (10th Cir. 1951) (applying Oklahoma law); Kaiser Foundation Hosps. v. North Star Reins. Corp., 90 Cal. App. 3d 786, 153 Cal. Rptr. 678 (2d Dist. 1979) (relying on Northwestern Mut. Ins. Co. v. Farmers Ins. Group, 76 Cal. App. 3d 1031, 143 Cal. Rptr. 415 (4th Dist. 1978)); Western World Ins. Co. v. Allstate Ins. Co., 150 N.J. Super. 48I, 376 A.2d 177 (1977) (relying on Estate of Penn v. Amalgamated Gen. Agencies, 148 N.J. Super. 419, 372 A.2d 1124 (1977)). In each of these cases the courts misread the law, reading the earlier cases in their jurisdictions as allowing recovery based on a duty of good faith owed by one insurance carrier to the other. In fact, those cases permitted only a subrogation action derived from a duty of good faith owed to the insured. For a further discussion of the Kaiser case and a more recent example of this misunderstanding of the law, see note 64 infra.

28. 94 Cal. App. 3d 124, 156 Cal. Rptr. 360 (3d Dist. 1979). 
of Appeal held that each of the parties in the three-party relationshipthe primary and excess insurers and the insured-owed the others a duty of good faith in approaching settlements. The extent of that duty depends on the control that each party has over the settlement process. In Commercial Union Assurance Companies v. Safeway Stores, Inc. ${ }^{29}$ the First District Court of Appeal adopted the holdings of Peter and Northwestern Mutual, holding that the only direct duty of good faith im settlement annong the three parties is that owed the insured by the primary insurer. All other causes of action, the court held, arise by equitable subrogation.

\section{A. Transit Casualty Company v. Spink Corporation}

Spink Corporation, an engineering firm, was the consulting engineer on a construction project owned by a third party. Spink was covered by two imsurance pohicies-a primary professional liability insurance policy with a limit of $\$ 100,000$ and a $\$ 15,000$ deductible feature, and an umbrella pohcy issued by the Transit Casualty Coinpany covering claims between $\$ 100,000$ and $\$ 1,000,000$. Both policies contamed clauses permitting Spink to refuse consent to any proposed settlements. ${ }^{30}$

An accident at the construction site resulted in several deaths and imjuries. Suits were brought agamst several defendants, mcluding Spink, who was charged with neghigent supervision of the project. The plaintiffs offered to settle the case. Spink's share of the proposed settlement was $\$ 76,000$, which was within the primary policy limits. Spink refused the offer, based on its insurance broker's advice that a settlement would impair the future insurability of Spink and of the engineering industry. The case went to trial, and the court found Spink liable. Transit, the excess insurer, was required to pay $\$ 175,000$ to satisfy the judgment. Transit then sued Spink and the primary insurer, charging that the rejection of the settlement offer was unreasonable and had caused it to pay out $\$ 175,000$, which it otherwise would not have had to pay.

The trial court found for Transit, and the court of appeal affirmed. The court noted that the purchase of an excess insurance pohicy creates a relationship between the excess and primiary insurers despite the lack of contractual privity between the insurers. The court further observed

29. 158 Cal. Rptr. 97 (Ist Dist. 1979), aff d, 26 Cal. 3d 912, 610 P.2d 1038, 164 Cal. Rptr. 709 (1980).

30. The clause provided that should Spink refuse to consent to any settlement recommended by the insurer, the insurer's liability would not exceed the amount for which the claim would have been settled, plus costs and expenses incurred up to that date. The Transit policy incorporated the terms of the primary pohicy, including this clause. 94 Cal. App. $3 d$ at $129 \mathrm{n} .1,156 \mathrm{Cal}$. Rptr. at 363 n.1. 
that the two insurers become aware of one another when the need to settle a large claim against the insured arises, even if they were previously ignorant of one another's coverage. ${ }^{31}$ This observation led the court to conclude that the concept of equitable subrogation was an "ancient artificiality" that was ill-suited to govern the relationship between the imsurers, because it required the excess carrier to use the insured as a stepping stone im order to assert the primary carrier's obligation and because the excess carrier could inherit only those rights that the insured could assert against the primary insurer. ${ }^{32}$

In place of equitable subrogation, the court established a system of "triangular reciprocity." ${ }^{33}$ Four principles of tort law formcd the foundation for this system of duties: (1) negligence, ${ }^{34}$ (2) the duty of care arising from the reasonable foreseeability of harin to another, ${ }^{35}$ (3) comparative negligence, ${ }^{36}$ and (4) joint and several liability. ${ }^{37}$ According to the Spink court, the confluence of these principles creates reciprocal duties of care in the conduct of settlement negotiations whenever a claim threatens to exceed the limits of primary coverage, despite the absence of contractual privity between the two insurers. Thus, in an action based on an unreasonable failure to settle, the court would assess dainages in accordance with each party's proportion of negligence. ${ }^{38}$

In addition, the court criticized the consent-to-settlement clause in Spink's imsurance policies as tending to defeat the "public imterest in extrajudicial settlement of lawsuits." ${ }^{39}$ Consistent with this interest and with its theory of reciprocal liability, the court construed the clause narrowly as not permitting the insured to rejcct a settlement offer "unreasonably." 40 The court read the clause as giving the insured only the

31. The court stressed the fact that when the prospect of a judgment in excess of the primary policy limits threatens both carriers with pecuniary loss, the two carriers face "interacting problems of claim adjustment, settlement and defense." Id. at 133, I56 Cal. Rptr. at 365.

32. Id. at 133, 156 Cal. Rptr. at 365-66.

33. Id.

34. Presently codified at CAL. Civ. CODE \& 1714(a) (West Supp. 1980): "Every one is responsible, not only for the result of his willful acts, but also for an injury occasioned to another by want of ordinary care or skill in the management of his property or person."

35. 94 Cal. App. 3d at 134, 156 Cal. Rptr. at 366.

36. This principle provides for liabihty in proportion to fault. See, e.g., Li v. Yellow Cab Co., 13 Cal. 3d 804, 532 P.2d 1226, 119 Cal. Rptr. 858 (1975). The doctrine was enacted to avoid the harsh results of contributory negligence, which completely barred recovery to plaintiffs who had contributed in any way to their own injuries.

37. See, e.g. American Motorcycle Ass'n v. Superior Court, 20 Cal. 3d 578, 578 P.2d 899, $146 \mathrm{Cal}$. Rptr. 182 (1978). Under this doctrine, multiple defendants whose negligence together caused an injury are each liable individually for the entire loss. Apportionment of the judgment among the defendants can be achieved by means of cross-complaints, with assessments to be made based on each defendant's degree of negligence.

38. 94 Cal. App. 3d at 134, 156 Cal. Rptr. at 366.

39. Id. at 136, $156 \mathrm{Cal}$. Rptr. at 367.

40. Id. 
opportunity to argue that its refusal to consent was reasonable under all of the circumstances. ${ }^{41}$

\section{B. Commercial Union Assurance Conıpanies v. Safeway Stores, Inc.}

Safeway held a hability insurance policy insuring it for liability up to $\$ 50,000$. Safeway carried no insurance for liability between $\$ 50,000$ and $\$ 100,000$. Commercial Union Assurance Companies and Mission Insurance Company insured Safeway for liabilities in excess of $\$ 100,000$ to a limit of $\$ 20$ million.

Safeway was sued in superior court, and suffered an adverse judgment for $\$ 125,000$. The excess insurers were required to pay $\$ 25,000$ to discharge their obligations under the policies, and sued Safeway and the primary imsurer to recover that amount. They alleged that the imsured and the primary carrier had an opportunity to settle the case for $\$ 50,000$ or $\$ 60,000$ and that the defendants knew or should have known that there was a likelihood that liability would exceed $\$ 100,000$ if the case went to trial. The plaintiffs predicated their action on allegations that the defendants had been neghigent and had breached the reciprocal duties of good faith and fair dealing, asserting that Safeway had a duty to settle the claim for less than $\$ 100,000$ when presented witl the opportunity to do so.

The trial court sustained Safeway's demurrer to the coniplaimt, and gave the plaimtiffs twenty days' leave to amend. It then disnissed the complaint when the excess imsurers failed to amend their conplaint, and the insurers appealed.

The court of appeal affirmed the trial court's ruling. The court first noted that the California courts pernit an excess carrier to sue a primary insurer for a bad faith refusal to settle. However, the court stated that the excess carrier's cause of action is based on equitable subrogation only, and not on any separate duty owed to the excess carrier. ${ }^{42}$

The court agreed with the excess carrier's contention that the duty of good faith and fair dealing implicit in every insurance contract applies to the insured and the msurer alike. ${ }^{43}$ To determine the scope of that duty, the court looked to the imsurance contract itself. The court

41. The court indicated that an insured's coucern for its professional reputation would be a factor in favor of reasonableness. Id.

42. Conmercial Union Assur. Cos. v. Safeway Stores, Inc., 158 Cal. Rptr. 97,99 (1st Dist. 1979) (citing Northwestern Mut. Ins. Co. v. Farmers Ins. Group, 76 Cal. App. 3d 1031, 1040, 143 Cal. Rptr. 415, 420 (4th Dist. 1978)). The court ignored the Spink court's contrary holding on this point.

43. 158 Cal. Rptr. at $99-100$. 
noted that the insurance policy's provisions that the insurer would defend and indemnify the insured in the event of a claim creates a legitimate expectation on the part of the insured that the insurer would make reasonable efforts to settle the case within the insurer's policy limits. ${ }^{44}$

On the other hand, the court said, the insured is under no duty to defend or indemnify its excess insurer. Thus, the excess carrier can have no reasonable expectation that the insured will accept a settlement proposal in order to protect the carrier from exposure. ${ }^{45}$ The court also noted that protection of the carrier's pecuniary interests is not the object of the excess insurance contract. Most msureds obtain excess insurance as protection in case they decide to litigate a claim. ${ }^{46}$ Therefore, an insured's duty to settle could not be implied from the insurance contract itself. The court said that the excess insurer could protect itself from any loss occasioned by an insured's failure to accept a reasonable settlement offer by requiring policy language limiting the insured's freedom to reject settlement offers. ${ }^{47}$ The court declined to follow Spink to the extent that it held that an imsured's duty of good faith and fair dealing implied an obligation to accept a settlement offer whenever there is a substantial likelihood that an adverse judgment would exceed the primary msurer's policy limits. ${ }^{48}$

The California Supreme Court granted certiorari in Commercial Union in order to resolve the conflict between that case and Spink. ${ }^{49}$ The court affirmed the Commercial Union court's judgment, adopting the lower court's opinion almost verbatim. Justice Newman concurred in the judgment but suggested that it would have been consistent with California court practice merely to depubhish Spink..$^{50}$ Chief Justice Bird concurred in the result but dissented from the form of the opinion. ${ }^{51}$

44. Id. at 100.

45. Id.

46. Id.

47. Id. at 102.

48. Id. at 101-02.

49. Commercial Union Assur. Cos. v. Safeway Stores, Inc., 26 Cal. 3d 912, 915, 610 P.2d 1038, 1039, 164 Cal. Rptr. 709, 710 (1980).

50. Id. at 921,610 P.2d at 1043, 164 Cal. Rptr. at 714 (Newman, J., concurring).

51. Id. at 922, 610 P.2d at 1043, 164 Cal. Rptr. at 714 (Bird, C.J., concurring and dissenting). Chief Justice Bird objected to the practice of issumg "by the court" opinions on the ground that important issues should not be decided anonynously. Id. (citing In re Perrone C., 26 Cal. 3d 49, 58, 603 P.2d 1300, 1306, 160 Cal. Rptr. 704, 710 (1979) (Bird, C.J., concurring and dissenting)). 


\section{III \\ ANALYSIS \\ A. The Insured's Duty to Settle}

The Commercial Union opinion stressed a vital difference between the duty of good faith asserted by the insured in Brown, Comunale and Crisci and that asserted by an excess insurer against the insured. The imposition of a duty of good faith on primary insurers is justified by the insurer's retention of control over the negotiation and settlement process. Retention of that power creates the possibility that the insurer will ignore the interests of the insured when the parties' pecuniary interests diverge, even though the insurance policy was intended to provide the insured with financial security. Because insurance coinpanies usually possess such superior bargaining power that they are able to dictate the terms of an insurance contract, including the clause giving them the exclusive right to handle liability claims against the insured, such a duty seems proper to protect the interests of the imsured. Moreover, imposition of a duty to accept reasonable settleinent offers tends to elimmate the perceived divergence between the interests of the insurer and those of the insured, thus removing the insurer's incentive to act contrary to the interests of the insured.

The situation presented in Spink and in Commercial Union bore an appealing but superficial resemblance to the situation giving rise to the insurer's duty to settle. In Spink and Commercial Union, the insured had some degree of control over the settleinent process, but the excess insurer had none. In Spink the msured had bargained for the right to withhold consent to settleinent proposals, a provision not normally found in insurance policies. ${ }^{52}$ In Commercial Union the insured chose not to carry insurance at a certain level of liability, and thus had control over the settleinent process at that level. ${ }^{53}$ To the Spink court, this retention of control over the process that determined the financial exposure of the excess insurer justified the imposition of a duty of good

52. C. Elliotr \& E. Vaughan, Fundamentals of Risk Insurance 448 (1972). Such a provision, however, is common in professionaI liability insurance policies. Id. See also Parish, Professional Liability Insurance, in Property and Liability Insurance HandBook 478, 487 (J. Long \& D. Gregg eds. 1965). In fact, some states may require insurers that provide certain types of professional coverage to obtain the consent of the insured before entering into a settlement. E.g. , Cal. Health \& Safety Code $\$ 1306$ (West 1979) (prohibiting insurers that provide professional liability insurance to health care facihities from entering into settlements in excess of $\$ 3,000$ without the written consent of the insured).

53. This fact raises a possible but unconvincing argument in favor of imposing a duty on the self-insurer to the excess insurer. This argument ignores the fact that the self-insurer pays premiums to the excess carrier in return for the assurance that its funds will be available should liability exceed a certam sum. Furthermore, insurance carriers are in a position to protect themselves by attaching conditions to the release of their funds, see note 58 infra, such as requiring consultation with the excess insurer whenever there is the possibility of an excess judgment. 
faith on the insured analogous to that owed to the insured by the primary insurer. ${ }^{54}$

However, the Spink court ignored an important differenee between the case before it and traditional bad faith cases. It is part of the insurer's everyday business to anticipate the risks involved in insurance contracts. Insurers, unlike insureds, are in the business of assessmg the likelihood and costliness of financial liability, and charge premiums sufficient both to cover the risks they cloose to undertake and to leave a margin for profit. ${ }^{55}$ Insurers are under no duty to issue policies and are not coinpelled to give the insured a contractual right to withhold consent to a proposed settlement. ${ }^{56}$ Thus, if an excess insurer issues a policy with full knowledge of the existence of a consent-to-settlement clause-as is generally true where the primary insurance contract contains such a clause ${ }^{57}$ - the imsured is justified in believing that the excess insurer has taken account of the risk that the insured will exercise its right to refuse consent to a proposed settlement and that the insurer has charged a higher premium im light of that risk. ${ }^{58}$

The Spink court also cited the public interest in the extrajudicial

54. 94 Cal. App. 3d at 136, 156 Cal. Rptr. at 368.

55. Although individual insurance companies take different things into account or assign different weights to certain factors in calculating expectations of loss, all insurers take certain basic precautions before writing an insurance policy. Generally, the company must ascertain that the imsured has an insurable interest, that the insured is affirmatively interested in the nonoccurence of the loss-producing event, that the cost of the loss to the insured is reducible to monetary terms, and that the probabihity that the loss will occur is susceptible of prediction over the long run. The insurance company's ability to calculate the latter two items enables it to devise a schedule of premiuns that will enable it to write a given kind of policy for a given class of similarly situated imsureds and make a profit over time. See Long, The Mechanism of Insurance, in ProperTY AND LiABILITY INSURANCE HANDBOOK 30, 35-39 (J. Long \& D. Gregg eds. 1965).

56. But see note 52 supra.

57. Excess insurance may be "straightforward," providing coverage only where it is provided in the underlying primary policy, or it may be "umbrella" coverage, providing protection from more types of losses than the primary policy. Both types of excess insurance are written with reference to the underlying prinary insurance carried by the insured. See Dainzer, Excess Liability, Umbrella, Aggregates, and Deductibles, in Property and Liability Insurance Handiook 600 (J. Long \& D. Gregg eds. 1965). The cost of both types of excess insurance is adjusted with relation to the primary policy limits, $i d$. at 605,615 , and exeess insurers generally require the insured to purchase a certain type of underlying prinary coverage based on an assessment of its risks as a prerequisite to the issuance of an unbrella policy. C. Elliort \& E. VAUGHAN, FundAMENTALS OF RISK AND 1NSURANCE 449 (1972). Thus it is fairly unlikely that an unbrella insurer, at least, will be unaware of the existence of a consent-to-settlement clause in the underlying primary policy.

58. The Commercial Union court noted a related point: the excess insurer has the freedom to linit the insured's right to take advantage of the consent-to-settlement clause in the insured's primary policy by bargaining for and inserting language to that effeet in the excess policy. $26 \mathrm{Cal}$. 3d at 921, 610 P.2d at 1043, 164 Cal. Rptr. at 714. The liniting language inust be unambiguous, however, as California courts have placed the burden of preeise draftsmanship on the insurance coinpanies and will construe anbiguities in favor of the insured. Bareno v. Employers Life Ins. Co., 7 Cal. 3d 875, 500 P.2d 889, 103 Cal. Rptr. 865 (1972). 
settlement of lawsuits in support of its holding, ${ }^{59}$ assuming that exercise of the insured's right to refuse consent would defeat that interest. However, reading a consent-to-settlement clause narrowly to require reasonableness in its exercise would defeat the public and private interests in certainty in msurance contracts. There are many reasons why an insured might want a consent-to-settlement clause in its policy, ${ }^{60}$ and the right to refuse a settlement offer may be of great value to the insured. The Spink court's reasonableness requirement would impose an external standard on contract construction with little certainty of application. The possibility that a judge or jury would second-guess tlie insured's decision would diminish the insured's right to withhold consent from settlement proposals, even though it may have bargained specifically for that right. Such a result would defeat the insured's reasonable expectations from the bargain. Moreover, the prospect of litigation over its choice would chill the insured's willingness to exercise its right to refuse consent if there were any uncertainty as to whetler a reviewing court would view its action as reasonable. ${ }^{61}$

The Commercial Union court looked to the reasons behind excess insurance for another argument against imposing a reasonableness requirement on insureds. A primary insurer with full control over the settlement process owes a duty of good faith in settling a claim agamst the imsured because the policy is meant to protect the insured, and the insured has a right to rely on the insurer to do nothing to dimimish that protection. However, an insured witl some control over the settlement process should not owe a duty of good faith to an excess insurer simply because the excess insurer has no such control. A primary insurance policy with finite limits leaves the insured exposed for all liability beyond those limits, and the function of an excess insurance policy is to provide additional coverage for the insured in those ranges in which it otherwise would be exposed. In the words of the court, "protection of the insurer's pecuniary interests is simply not the object of the bar-

59. 94 Cal. App. 3 d at 136,156 Cal. Rptr. at 367.

60. The professional liability setting in Spink provides an example of the type of case in which the insured's desire to have a direct say in the conduct of settlement negotiations nay be particularly acute. The insured might validly fear that his professional reputation would be irreparably tarnished were he to admit to more than a certain amount of professional negligence in a settlement. In some cases, nothing short of a complete judicial exoneration will save the insured's reputation-as, for example, where media coverage of the events giving rise to a claim has widely publicized the insured's predicament. To protect the insured in certain types of professions, some states now require professional liability insurers to obtain the insured's consent to a proposed settlement of more than a specified amount. See note 52 supra.

61. Under a reasonableness standard, the insured generally should accept a proposed settlement whenever there is any likelihood of a judgment that would call excess insurance into play. Under current California law, the judgment would raise an inference that settleinent below the excess insurance threshold was the most "reasunable" way of disposing of the claim. See note 17 and accoinpanymg text supra. 
gain."62 Thus, there is nothing in the contract between the excess insurer and the insured that would justify imposing on the insured a duty to settle in order to protect the interests of the excess insurer. The excess insurer has no contractual basis for an expectation that the insured will take its interests into account in the settleinent process. Thus, there is no basis for a duty on the part of the insured to accept reasonable settleinent offers.

\section{B. The Nature of the "Duty" Between Insurers}

While the supreme court was correct in deciding that there is no direct duty of good faith between insurers, its failure to disapprove the Spink case on this point is regrettable. The Commercial Union court explicitly disapproved Spink only to the extent that it imposed on the insured a duty of good faith in settling claims. ${ }^{63}$ It did not, however, mention Spink in its treatment of the nature of the cause of action between insurers, even though Spink and Commercial Union reached contradictory results. This omission inight be given undue weight by future courts, which might re-impose a direct duty between insurers in soine circumstances, even though the substantive holding of Commercial Union appears dispositive of the issue. ${ }^{64}$ The court should have rejected the Spink opinion on this point as well in order to clarify its position.

Thus, while the court failed to eliminate the potential confusion in the law, ${ }^{65}$ its resolution of the issues presented in the case was correct.

62. 26 Cal. 3d at 919,610 P.2d at 1042, 164 Cal. Rptr. at 713.

63. Id. at 921,610 P.2d at 1043,164 Cal. Rptr. at 714 .

64. The ease with which courts might misread the law in this area is illustrated by Commercial Union's treatment of Kaiser Foundation Hosps. v. North Star Reins. Corp., 90 Cal. App. 3d 786, 153 CaI. Rptr. 678 (2d Dist. 1979). In Kaiser, a court of appeal stated that an insured and a primary insurer could be held jointly liable to an excess insurer for breach of a duty of good faith for allocating losses to certain dates without regard to the effect that the allocation had on the excess carrier's liability. Kaiser clearly imposed a duty of good faith on the primary carrier toward the excess insurer. The Commercial Union opinion, however, merely distinguished Kaiser on its facts rather than disapproving it, 26 Cal. 3d at 921,610 P.2d at 1043, 164 Cal. Rptr. at 71314 (reading Kaiser only as recognizing that the insured has no license "to engage in unconscionable acts which would subvert the legitimate rights and expectations of the excess insurance carrier"), whicl might indicate that the court viewed Kaiser as good precedent in cases in which the bad faith of the insured and the primary insurer can be characterized as collusive or that it was simply unaware that Kaiser was inconsistent with the court's lolding that there is no duty of good faith between insurers. For another example of a misreading of the law in this area, see Signal Cos. v. Harbor Ins. Co., 27 Cal. 3d 359, 365, 612 P.2d 889, 893, 165 Cal. Rptr. 799, 803 (1980), in which the court stated: "[A]s we recently noted in Commercial Union, . . . the primary carrier, in settling an action, owes a duty of good faith to the excess carrier based on the theory of equitable subrogation." Equitable subrogation, however, does not contemplate any duty between insurers, and the Commercial Union court did not create such a duty. Rather, it is a vehicle by which the excess insurer, after discharging the insured's liability, takes over whatever cause of action the insured may have against the primary insurer.

65. The potential for confusion is furthered by the holdings of cases similar to the excess 
An excess carrier's only action against a primary insurer is therefore in equitable subrogation. This action, however, is subject to any defenses that the primary carrier could interpose between itself and the insured. ${ }^{66}$ It might seein unfair that an excess insurer's cause of action against a primary insurer can be defeated by the actions of a third party, which the excess carrier is powerless to control or arguably even to investigate, ${ }^{67}$ particularly where the potential dainages are large. ${ }^{68}$ However, this miperfection in the excess insurer's equitable subrogation remedy does not justify the creation of a duty of good faith between insurers that did not contract with one another and whose

insurer situation. In Royal Globe Ins. Co. v. Superior Court, 23 Cal. 3d 880, 592 P.2d 329, 153 Cal. Rptr. 842 (1979), the supreine court allowed the plaintiff in a personal injury case to sue the defendant's insurer directly for bad faith in failing to accept a settlement offer once the defendant's liability had become reasonably clear. The court reached this result by applying a California statute that provides, in relevant part, that it is an

unfair and deceptive act or practice in the business of insurance.

…

(h) Knowingly commiting or performing with such frequency as to indicate a general business practice any of the following unfair claims settlement practices:

$\ldots$...

(5) Not attempting in good faith to effectuate prompt, fair, and equitable settleinents of claims in which liability has become rcasonably clear.

CAL. INS. CODE $\$ 790.03(\mathrm{~h})(5)$ (West Supp. 1981). The court required a judgment agaimst the defendant as a prerequisite to a suit against the insurer under this section, but there was no finding that the insurer had engaged in similar conduct on other occasions, as the literal wording of the section would seem to require. The Royal Globe court was faced with a clear precedent, Murphy v. Allstate Ins. Co., 17 Cal. 3d 937, 553 P.2d 584, 132 Cal. Rptr. 424 (1976), which held that there was no duty of good faith running from a defendant's insurer to a plaintiff due to the absence of privity of contract. The court distinguished this case without overruling it, on the ground that the plaintiff in Royal Globe sought to invoke a duty created by statute while the Murphy plaintiff sought to invoke a common law duty. 23 Cal. 3d at 889-90, 592 P.2d at 335, 153 Cal. Rptr. at 848. See Note, Royal Globe Insurance Co. v. Superior Court: Right to Direct Suit Against an Insurer by a Third Party Claimant, 31 Hastings L.J. 1161 (1980). On the strength of this dubious distinction, it is possible to imagine excess insurers atteinpting to hold primary insurers hable for breach of statutory duty rather than confining theinselves to the reinedy of equitable subrogtion. The Commercial Union opinion inakes no mention of Royal Globe, indicating that perhaps the court failed to consider this possibility.

66. Patent Scaffolding Co. v. William Sinpson Const. Co., 256 Cal. App. 2d 506, 510, 64 Cal. Rptr. 187, 190 (2d Dist. 1967). An example of such a defense is a claim by the primary insurer that its duty to defend the insured was nullified at the outset by a willful misrepresentation of inaterial facts or other deceit on the part of the insured. See also note 69 infra.

67. It is the duty of the primary insurer to investigate the background of the insured and to discover anything that might entail a risk before issuing a policy, including misrepresentations of facts or other instances of bad faith on the part of the insured that inight be discoverable. See, e.g., Long, The Mechanism of Insurance, in PROPERTY AND LiabiLITY INSURANCE HANDBOok 30, 35-39 (J. Long \& D. Gregg eds. 1965). Although prudence generally dictates that an excess insurer undertake its own investigation of the insured before agreeing to insure, it may not have as ready access to all the facts as the prinary insurer did, and thus the excess insurer may have to rely on the word of the insured and the primary insurer to soine extent.

68. Historically, the amount of money in controversy between insurers has grown as plaintiffs' demands from and jury verdicts against insured defendants have increased. See Bloom, Recovery Against Primary Insurer by Excess Carrier for Bad Faith or Negligent Failure to Settle, 36 INS. COUNSEL J. 235 (1969). 
relationship is largely fortuitous. A direct duty of good faith would make the primary insurer liable to the excess insurer despite the insured's affirmative fraud or bad faith, which voids the primary contract altogether, so long as the primary insurer was unable to discover the insured's malfeasance in the exercise of reasonable diligence. ${ }^{69}$ Arguably, the burden of reimburseinent for bad faith should be borne by the insured, not the primary carrier, if the excess insurer suffers a loss that it cannot recover under equitable subrogation.

Between insurers, however, the burden of such a loss is best allocated to the excess insurer. The excess insurer is almost always aware of the existence of the primary insurer, and usually writes its policy with reference to the provisions of the primary policy. In fact, the excess insurer soinetimes makes the purchase of a particular kind of primary insurance a prerequisite to the issuance of an excess policy. ${ }^{70}$ By contrast, the primary insurer is less likely to be aware of the existence of the excess insurer. The courts might hold the primary carrier responsible for foreseeing that the insured will buy excess insurance, ${ }^{71}$ but it is unlikely to be aware of the specifics of an excess insurance policy, because it does not write its policies with reference to an excess policy. ${ }^{72}$ As a result, the excess insurer usually is in the better position to inform itself of the details of the other insurer's policy, including any consent-to-settlement clause or other unusual features, and to protect itself accordingly. ${ }^{73}$ In the absence of a showing that the excess insurer

69. For example, in cases in which the insurer has exercised reasonable diligence in attempting to secure the cooperation of the insured, willful unisrepresentation or concealment of facts by the insured that prejudices the insurer's ability to defend a clain against the insured would be treated as voiding the insurer's obligations under the insurance policy. Valladao v. Fireman's Fund Ins. Co., 13 Cal. 2d 322, 89 P.2d 643 (1939).

70. See note 57 supra.

71. An increasing trend toward the purchase of excess insurance as opposed to self-insurance for high levels of liability is noted in Dainzer, Excess Liability, Umbrella, Aggregates, and Deductibles, in Property and Liability InsuranCE Handbook 600 (J. Long \& D. Gregg eds. 1965). Persons who fear the possibility of catastrophic liability loss, such as professionals, are especially likely to purchase excess insurance. See C. Elliott \& E. Vaughan, Fundamentals of Risk AND INSURANCE 448-49 (1972).

72. For a discussion of the factors on which primary insurers do rely in writing their policies, see Long, The Mechanism of Insurance, in PROPERTY AND LIABILITY INSURANCE HANDBOOK 30, 35-39 (J. Long \& D. Gregg eds. 1965); note 55 supra.

73. For example, the excess insurer may charge a somewhat higher premium to take account of the risk that actions of the msured might defeat its equitable subrogation claim against the primary insnrer, or it might bargain for a provision in the insurance contract excusing it from its obligation to indemnify the insured if its claim for subrogation is negated by an action of the insured. The Commercial Union court noted the latter possibility. 26 Cal. $3 \mathrm{~d}$ at $921,610 \mathrm{P} .2 \mathrm{~d}$ at 1043, 164 Cal. Rptr. at 714.

Alternatively, the insurance industry itself could take steps to minimize conflicts of this type between excess and primary insurers. To this end, the industry has suggested a set of voluntary Guiding Principles to govern the interaction between primary and excess insurers when it appears that an insured may be exposed beyond the limits of the primary policy. Guiding Principles for 
was not in the better position to protect itself in a particular case, ${ }^{74}$ the best rule is to require it to protect itself in the contract rather than to impose a duty of good faith on the primary insurer toward a party with which it did not contract and which is potentially broader than the duty it owes to the insured.

The Spink court based its theory of triangular reciprocity on tort principles because the court reasoned that "dainage recovery for refusal to settle is inore delictual than contractual"75 and that the test for liability in such a case is similar to a neghigence standard. ${ }^{76}$ The court thus overlooked or disregarded the fact that since Comunale, the California bad faith action had containcd eleinents of both tort and contract, ${ }^{77}$ and that the courts have taken pains to disassociate it, at least verbally,

Iusurers of Primary and Excess Coverages, reprinted in Hardies, Guiding Principles (and Principals) in Primary and Excess Problems, 1977 INS. L.J. 469, 484-86. The Principles were published in 1974 after several years of study by the Claims Executive Council, composed of the claims coinmittees of the Ainerican Insurance Association, the American Mutual Insurance Alliance, and eight unaffiliated companies. $I d$. at 470 . A preliminary statement calls on the prinary insurer voluntarily to adopt the saine standards of conduct when dealing with an excess insurer as it would be required by law to adopt toward the insured. The Principles also urge the primary carrier to make reahistic evaluations of liability on a claim without regard to the policy limit, to attempt settlement proinptly of up to the policy limit whenever feasible, and to notify the excess insurer whenever it appears that liability may exceed the primary policy limits, providing the excess carrier with the results of any investigations or negotiations and inviting the excess insurer to participate in a common effort to dispose of the claim. The Principles also urge the excess carrier to refrain from coercive or collusive conduct designed to force a settlement, and attempt to formulate rules regarding the allocation of costs of appeal and interest on judginents in the event that only one of the two imsurers elects to appeal.

So far, the Principles have been ineffective in bringing about greater cooperation between insurers. Hardies speculates that this steins from a general unawareness of the Principles in the insurance industry. The Principles have also been criticized on the ground that they would free the primary insurer from liability for the costs of an appeal once it guarantees paynent of its policy limits. Thus, they provide a disincentive for the primary carrier to join an appeal unless its monetary involvement in the judgment is very large relative to the costs of appeal plus interest on the judgment. They therefore create an increased liability exposure for the excess insurer which may not have been contemplated when the premiun was deternined. Lanzone, Duties Owed by a Primary Insurer and an Insured with a Self-Insured Retention to an Excess Insurer-An Update, 28 FED'N OF INS. COUNSEL Q. 267, 278-79 (1978). The most fundamental objection to the Principles, however, is that they provide no real incentive for coinpliance except that an insurer that consistently refuses to comply umght gain an unfavorable reputation within the industry. Given the extent to which the Principles recommend actions that are against the primary insurer's perceived self-imterest, voluntary compliance is unlikely.

74. The excess insurer inight be able to show, for example, that the policy that it wrote for its insured did not refer to the specifics of the underlying primary policy, or that the primary policy was written with reference to, or in specific conteinplation of, provisions of the excess policy other than its monetary limits. Such cascs are exceptional, however, and an "unbrella" policy is always written in contemplation of at least some of the nonmonetary terms of the priunary policy. See note 57 supra.

75. 94 Cal. App. 3d at 133, 156 Cal. Rptr. at 365.

76. Id. at 133, I56 Cal. Rptr. at 366. See also Blooin, supra note 68, at 235; note 12 supra.

77. See text accoinpanying notes 13-18 supra. 
from concepts of negligence. ${ }^{73}$ Within this hybrid framework, the equitable subrogation remedy is workable because it attempts to achieve a fair result in accordance with the parties' reasonable expectations. Equitable subrogation ensures that the primary insurer has an incentive to accept reasonable settleinent offers regardless of whether the insured purchased excess insurance, thus keeping some litigation out of the courts. Moreover, the duty imposed on the primary insurer is neither broader nor less predictable than the duty owed to the insured in the absence of excess insurance.

In contrast, adoption of the Spink court's direct duty between insurers would have created uncertainty in the insurance field. The primary insurer, responsible for conducting settlement negotiations, would not know whether it would be subsequently held liable to an often unknown excess insurer, since it would not know when the courts would deem its actions "reasonable" in light of the excess insurer's interests. Such uncertainty in the settlement process would be likely to result in either considerably higher insurance rates or a decreased availability of msurance. The supreme court's rejection of the Spink approach is thus practically wise as well as legally sound.

\section{CONCLUSION}

In Commercial Union, the supreme court concluded that a primary insurer has no duty to an excess insurer to settle claims analagous to the duty owed by the primary insurer to the insured. The court emphasized the contractual nature of the duty of good faith and held that the excess imsurer could only sue the primary insurer under a theory of equitable subrogation in the absence of any contractual agreement between the two insurers. While its analysis is sparse, the court reached the correct result. The risk of loss from the imsured's bad faith is more appropriately borne by the excess msurer because it is more likely to be acquainted with the particulars of the underlying primary insurance policy. In contrast, the primary insurer is unlikely to frame its policy with specific reference to the excess policy. Thus, the excess carrier can guard against the insured's bad faith more easily by charging a higher premium to account for that risk or by inserting a provision in its policy that limits the insured's right to withhold consent from settlement proposals.

The court also held that an insured owes its excess insurer no duty to accept reasonable settlement offers even if the insured has some control over the settlement process. The court correctly noted that the in-

78. See Brown v. Guarantee Ins. Co., 155 Cal. App. 2d 679, 687-88, 319 P.2d 69, 74 (2d Dist. 1967); text accompanying note 12 supra. 
surance contract gives the insurer no reason to expect the insured to protect the insurer's interests because the primary function of an excess insurance policy is to protect the insured froin high levels of liability. Like the risk of loss between insurers, the excess insurer can guard against the risk of an insured's failure to accept a "reasonable" settlement offer by charging a higher preinium or by inserting language in its policy limiting the freedom of the insured to reject proposed settlements. Commercial Union correctly focused on the contractual nature of the insurance relationship in resolving both issues and opted for contractual solutions to the problems posed. These solutions place the burden of risk on the party best able to bear them and avoid the uncertamty inherent in a judicially formulated duty grounded in tort.

Edward P. Errante*

* B.A. 1978, University of Arizona; third-year student, Boalt Hall School of Law, University of California, Berkeley. 